\title{
Adaptasi Anatomis Tumbuhan Terhadap Perbedaan Stress Lingkungan
}

\section{Plant's Anatomical Adaptation in Different Environmental Changes}

\author{
Hafidha Asni Akmalia ${ }^{1}$ \\ ${ }^{1}$ Program Studi Pendidikan Biologi, Fakultas Sains dan Teknologi, UIN Walisongo Semarang \\ Email: akmalia.h.a@walisongo.ac.id
}

\begin{abstract}
Abstrak
Adaptasi dilakukan oleh tumbuhan demi kelangsungan hidupnya di lingkungan yang sangat dinamis. Salah satu jenis adaptasi yang dikembangkan adalah adaptasi anatomis pada akar, batang, maupun daun. Tujuan review artikel ini yakni memberikan langkah yang dapat dilakukan manusia dalam membantu tumbuhan untuk menjaga adaptasi anatomisnya sehingga dapat mendorong pertumbuhan dan perkembangan tumbuhan di bawah stress lingkungan. Review ini didasarkan pada telaah pustaka pada artikel-artikel ilmiah yang membahas tentang adaptasi anatomis tumbuhan terhadap perbedaan stress lingkungan. Berdasarkan kajian yang dilakukan, perlu adanya upaya penelitian lebih lanjut guna menjaga tumbuhan tetap lestari di bawah stress lingkungan yang semakin menantang.
\end{abstract}

Kata kunci: adaptasi; anatomi; stress lingkungan

\section{Abstract}

Adaptations are carried out by plants for their survival in a very dynamic environment. An example of adaptation that has been developed is anatomical adaptation in root, stem and leaves. The purpose of this review article is to provide steps that humans can take in helping plants to maintain their anatomical adaptations so that they can promote plant growth and development under environmental stress. This review is based on a literature review of scientific articles that discuss the anatomical adaptation of plants to different environmental stresses. Based on the studies conducted, further research efforts are needed to keep plants sustainable under increasingly challenging environmental stress.

Keywords: adaptation; anatomy; environmental stress

\section{PENDAHULUAN}

Setiap tumbuhan mengembangkan ciri adaptasi yang berbeda untuk menghadapi stress lingkungan sekitar habitatnya seperti salinitas, panas, kekeringan, genangan, logam berat dan faktor nutrient (Fayçal Boughalleb et al., 2014; Mahajan et al., 2020). Studi terhadap pengaruh stress lingkungan terhadap tumbuhan dan adaptasi yang dilakukan tumbuhan merupakan subjek penelitian yang sangat berkembang cepat di dunia (Alkhatib et al., 2018) karena berbagai stress lingkungan yang ada menjadi faktor pembatas bagi produktivitas tumbuhan (Nio Song and Banyo, 2011; Osakabe and Osakabe, 2012). Penurunan produktivitas inilah yang selanjutnya dapat menurunkan kegagalan panen dan mengancam sektor agrikultur dunia (Mahajan et al., 2020). Tak hanya mengancam ketahanan pangan, tumbuhan yang berpotensi sebagai obat herbal juga akan terpengaruh karena metabolit sekunder yang dihasilkan sanbat bergantung pada kondisi lingkungan baik berupa faktor biotik maupun abiotik. Dengan demikian, tumbuhan melakukan survival agar bertahan hidup dengan mengembangkan mekanisme adaptasi.

Salah satu jenis adaptasi yang dilakukan yakni adaptasi anatomis yang sangat peka terhadap perubahan lingkungan (Naz et al., 2016). Adaptasi jenis ini merupakan salah satu bentuk adapatasi melalui perubahan atau pembentukan struktur yang membantu tumbuhan untuk menghadapi habitat ekstrim, pathogen, maupun kondisi lingkungan yang mengancam kehidupannya. Trikoma, metabolit sekunder, kutikula, dan perubahan ukuran sel adalah contoh adaptasi anatomis yang sering ditemukan. Adaptasi anatomi menjadi salah satu jenis 
adaptasi sangat penting bagi tumbuhan khususnya tumbuhan pangan yang dibutuhkan manusia. Misalnya pada kadar garam yang tinggi, tumbuhan pangan dapat mengalami penurunan produktivitasnya karena $\mathrm{NaCl}$ yang masuk akan menurunkan influx ion $\mathrm{K}$ yang penting untuk regulasi $\mathrm{pH}$ dan transport elektron di kloroplas (Zhao et al., 2020). Fotosintesispun akan terhambat dan terjadi penurunan produktivitas panen. Banyak review telah mengulas adaptasi fisiologis dan biokimia tumbuhan pada berbagai stress lingkungan sedangkan review tentang adaptasi anatomis tumbuhan belum mendapatkan perhatian luas. Review ini mengelaborasi berbagai jenis adaptasi anatomis tumbuhan pada stress lingkungan yang berbeda dengan tujuan untuk memberikan langkah yang dapat dilakukan untuk membantu tumbuhan dalam menjaga adaptasi anatomisnya yang dapat digunakan guna mendukung pertumbuhannya di bawah kondisi stress atau cekaman lingkungan.

\section{METODE PENELITIAN}

Peneliti mengumpulkan database saintifik dari artikel ilmiah yang berisi informasi terkait adaptasi anatomis tumbuhan terhadap perbedaan stress lingkungan. Artikel ilmiah yang digunakan berasal dari Google Scholar, Science Direct, Taylor and Francis, Mendeley, Springer link and Wiley online library.

\section{PEMBAHASAN}

Adaptasi anatomis yang terjadi pada organ tumbuhan umumnya pada akar, batang, dan daun.

\section{Daun}

Organ daun menjadi organ tumbuhan yang merespon perubahan lingkungan dengan cepat dibandingkan akar dan batang (ghafoor). Banyak struktur anatomis daun yang terbentuk untuk melindungi tumbuhan dari berbagai kondisi ekstrim seperti kekeringan, suhu udara yang tinggi, dan peningkatan konsentrasi garam di tanah. Daun Vaccinium corymbosum merespon paparan UV-B dengan mempertebal daun agar meminimalisasi radiasi UV-B pada apparatus fotosintetik (Reyes-Díaz et al., 2016). Pada spesies Z. album yang hidup di daerah kering dan kadar garam tinggi, daunnya berbentuk bulat untuk mengurangi luas permukaannya sehingga tidak terjadi penguapan yang berlebihan (Abd Elhalim et al., 2016), sedangkan pada Heritiera fomes memiliki perawakan yang kerdil pada kondisi habitat dengan kadar garam tinggi (M. N. I. Khan et al., 2020). Penebalan epidermis juga sering terjadi saat tumbuhan berada di tanah bergaram dengan tujuan untuk efisiensi pengunaan air dan mesekuestrasi garam di epidermis tersebut (Fayçal Boughalleb et al., 2017). Daun Z. album juga memiliki jaringan parenkim yang terisi air sebagai ciri dari tumbuhan sukulen. Sementara itu menurut (Adame-González et al., 2019), sebagai tanda khas dari tanaman xerofitik, daun Selaginella sp., yang tumbuh di lahan kering memiliki jaringan sklerenkim untuk penyokong organ dan menyebabkan daun meregang atau mengkerut tergantung kondisi air dalam daun. Penebalan epidermis dan kutikula menjadi adaptasi anatomis yang umum dilakukan tumbuhan di bawah stress kekeringan seperti pada Astrogalus gambiformis (Fayçal Boughalleb et al., 2014) serta penebalan sel-sel dalam daun untuk kelancaran aliran air (Gratani et al., 2013) juga penguat organ guna mencegah tumbuhan layu saat ketersediaan air tanah jarang (Lamalakshmi Devi et al., 2017). Adaptasi anatomis lainnya saat tanaman tercekam kekeringan yakni penurunan ukuran stomata dan densitas stomata pada Acacia mangium (D. Kartikaningtyas, O. Quirena, Suharyanto, 2013) juga Astrogalus gambiformis (Fayçal Boughalleb et al., 2017) serta lebar bukaan stomata dan area bukaan stomata yang disertai peningkatan massa daun dan densitas daun pada Q. ilex demi efisiensi kontrol pertukaran gas (Gratani et al., 2013). Pada daun Sporobolus ioclados memiliki sel buliform yang besar, meningkatnya jumlah trikoma dan penebalan pada epidermis (Naz et al., 2016) 
serta daun Scaevola plumieri memiliki kutikula tebal pada epidermis untuk mengurangi pengeluaran air dan menurunkan konsentrasi sodium di jaringan (Kuster et al., 2018). Daun Stipa lagascae juga memiliki sel buliform sebagai respon kekeringan untuk membantu daun menggulung sehingga mengurangi penguapan namun saat kekeringan berlanjut pada periode berikutnya, sel buliform mengecil sebagai akibat stress berkepanjangan (Façal Boughalleb et al., 2015).

Respon terhadap lingkungan sangat dimungkinkan berbeda tiap spesies. Studi (M. N. I. Khan and Kabir, 2017) menunjukkan bahwa stress nanungan menyebabkna luas permukaan daun lebih besar dan daunnya lebih tipis dengan klorofil yang banyak namun pada Zea mays kondisi tercekam intensitas cahaya rendah disertai kekeringan menyebabkan kadar klorofil juga berkurang sehingga produktivitas menurun (Akmalia, Hafidha Asni; E. Suharyanto, 2017). Selain itu, perbedaan habitat juga dapat menyebabkan respon berbeda bahkan pada spesies yang sama sekalipun. Pada C. cufodontisii yang hidup di daerah tinggi memiliki daun amfistomi yakni stomata ada di kedua permukaan adaxial dan abaxial daun. Fungsinya yakni untuk memaksimalkan konduktasi daun tehadap CO2. Pada Monochaetum sp., yang juga hidup di habitat sama dengan C. cufodontisii, mengembangkan mekanisme adaptasi berbeda terhadap ketinggian yakni dengan adanya hipodermis untuk melindungi palisade (Kriebel, 2015) namun kedua spesies yang sama di Venezuela tidak memiliki ciri anatomis yang sama dengan yang hidup di Costa Rica. Penelitian (Ely and Torres, 2003) menunjukkan bahwa C. cufodontisii dan Monochaetum sp., di Venezuela tidak memiliki daun amfistomi dan hipodermis. Ini menunjukkan bahwa pada habitat yang berbeda dapat memunculkan adaptasi anatomis yang berbeda pula sekalipun spesiesnya sama.
Pada lingkungan dengan polusi udara tinggi juga menyebabkan perubahan anatomi daun seperti terlihat pada kutikula yang menjadi pertahanan pertama dalam menghadapi paparan polutan. (Kulshrestha and Saxena, 2016). Struktur lilin epikutikular mulanya memiliki bentuk yang bagus dengan struktur kristalin namun seringin berjalannya waktu jika terkena hujan asam atau udara yang mengandung polutan dapat mengalami abrasi mekanis karena kontak dengan mikropartikel dalam udara terpolusi tersebut. Pada akhirnya hal ini dapat menyebabkan perubahan penampakan daun dan mempengaruhi afinitasnya pada air. Sementara itu, naungan menyebabkan daun lebih tebal, indeks stomata menurun dan berkas pengangkut lebih berkembang pada Rhododenron agastum (Zhou et al., 2017) namun tidak pada Plectranthus amboinicus (Ekawati and Aziz, 2016) dan Zea mays (Akmalia and Suharyanto, 2017) yang menunjukkan bahwa daun lebih tipis dan berkas pengangkut kurang berkembang. Pada studi (Gupta et al., 2016), polusi di kota besar juga menyebabkan kerusakan sel penjaga, epidermis, dan mengubah bukaan stomata secara signifikan dan menurunkan ukuran juga densitas stomata (Lamalakshmi Devi et al., 2017). Polutan tak hanya pada udara bebas melainkan juga dapat berupa zat cair seperti minyak. Studi kasus di Thailand, tumbuhan Terminalia catappa yang terpapar tumpahan minyak mengalami perubahan anatomi daun seperti penurunan densitas stomata, penebalan kutikula pada kedua sisi daun dan pembesaran sel-sel epidermis (Punwong et al., 2017). Kontaminasi minyak menstimulus terjadinya kondisi kekeringan karena minyak masuk ke dalam tumbuhan sehingga proses pembentukan stomata akan terganggu dan untuk mencegah minyak masuk dalam konsentrasi yang berlebih maka terjadi penebalan kutikula sebagai langkah pencegahan oleh tumbuhan. Polutan lain seperti $\mathrm{Zn}$ terindikasi meyebabkan penurunan densitas dan konduktansi stomata Arachis hypogea (Shi 
and Cai, 2009) dan logam berat lain juga menurunkan ukuran stomata Brassica olearea (Batool et al., 2015). Ancaman kekeringan juga dapat terjadi pada tumbuhan yang hidup di ketinggian. Pada Lupinus montanus memiliki sel-sel epidermis bagain adaxial yang lebih kecil dan indeks stomata pada Acaena elongate juga lebih sedikit (Jiménez-Noriega et al., 2017). Adaptasi anatomi ini dilakukan untuk mencegah penguapan air sehingga stomata yang dibentuk lebih sedikit dan ukuran sel epidermis diperkecil.

\section{Akar}

Berbagai adaptasi anatomis pada akar terhadap stress lingkungan tergantung pada jenis stress dan spesies. Phyllostachys vivax memilki eksodermis akar yang lebih tebal saat tercekam kekeringan dengan kadar garam tinggi (Ge et al., 2017) demikian pula Z. album dan Nitratia sp., pada kondisi cekaman yang sama juga memiliki adaptasi anatomisnya yakni selsel xylem yang dikelilingi oleh sel-sel berlignin (Abd Elhalim et al., 2016). Rupanya keberadaan sel berlignin untuk mencegah terjadinya embolisme pembuluh pengangkut dan memperkuat sel-sel akar di sekitarnya. Menurut (Rosawanti et al., 2015) embolisme adalah peristiwa terbentuknya gelembung-gelembung udara pada xylem sehingga dapat mengganggu konduktivitas air. Oleh sebab itu, perlu dilakukan adaptasi dengan adanya lignifikasi sel juga pengecilan diameter xylem. Sklerifikasi juga teramati di korteks dan empulur Sporobolus ioclades untuk penguatan akar (Naz et al., 2016). Sementara itu kekeringan juga menyebabkan akar seminal Zea mays (Grzesiak et al., 1999), Gycine max (Rosawanti et al., 2015), Astragalus gombiformis (Fayçal Boughalleb et al., 2014) dan Stipa lagascae (Façal Boughalleb et al., 2015) mengalami penurunan diameter akar, stele dan korteks. Stipa lagascae juga memiliki diameter xylem lebih kecil saat tercekam kekeringan untuk menjaga konduktivitas air (Façal
Boughalleb et al., 2015) sedangkan lapisan korteks yang tipis menjadi adaptasi anatomis untuk mempercepat aliran air dari epidermis ke berkas xylem (W.-D. Khan et al., 2020).

Tumbuhan dapat memodifikasi struktur internalnya ketika mengalami stress polutan ( $\mathrm{Li}$ et al., 2019) dan kebanyakan yang terjadi jika akar tercekam logam berat adalah penurunan ukuran sel (Batool et al., 2015). Keberadaan polutan seperti logam rupanya berdampak pada struktur anatomi akar. Alumunium dan $\mathrm{Pb}$ menghambat pembelahan dan pemajangan sel akar dengan merusak organisasi mikrotubul juga perkembangan akar dan menurunnya jumlah akar lateral pada Zea mays (Yadav et al., 2021) dan pada struktur akar kecambah Achnaterum splendens (Zhou et al., 2014). Polutan $\mathrm{Cu}$ pada Hordeum sativum (Minkina et al., 2020) juga merusak epidermis, sel-sel endodermal akar, serta menurunkan diameter stele akar sedangkan pada Sorghun bicolor (Lamalakshmi Devi et al., 2017) akan menurunkan diameter akar dan trakea xylem juga menurunkan jumlah lengan xylem. Selain itu, kerusakan parenkim korteks teramati juga pada Cynodon dactylon yang terkontaminasi Ni (Batool et al., 2015). Polutan lain juga dapat berasal dari obat atau limbah famasi misalnya Naproxen (NPX). Naproxen, yakni suatu obat antiinflamasi nonsteroid. Pada Pisum sativum yang terpapar NPX, mengalami penurunan jumlah sel-sel pada zona dimana akar lateral ditemukan, walaupun primordial akar lateral tidak terlalu terpengaruh (Svobodníková et al., 2020). Pada spesies Avicenna sp., (Li et al., 2019) dan Cynodon dactylon (Batool et al., 2015) adaptasi anatomis yang dimiliki terhadap stress $\mathrm{Cd}$ yakni cukup unik dengan mengakumulasi $\mathrm{Cd}$ pada bagian endodermis. Suberin pada pita Kaspari di endodermis memiliki ligand yang dapat mengakumulasi $\mathrm{Cd}$ di endodermis sehingga menghambat transport $\mathrm{Cd}$ ke berkas pengangkut. Polutan tak hanya berupa logam berat saja, melainkan juga dapat 
berupa zat pemicu pertumbuhan (growth enhancer) yang konsentrasinya justru dapat menjadi inhibitor pertumbuhan. Pada akar Nicotiana tabacum yang diberi cafein sebagai growth enhancer dengan konsentrasi $5000 \mu \mathrm{M}$ menunjukkan bahwa terjadi kerusakan mayor sel-sel korteks dan adanya penebalan dinding sel xylem (Alkhatib et al., 2018). Stress lain seperti genangan menyebabkan akar biasanya mengembangkan jaringan aerenkim seperti terlihat pada akar Ipomoea pes-caprae, Remirea maritima, Scaevola plumier (Kuster et al., 2018) dan Chrysanthemum zawadskii (Yin et al., 2012) untuk mengurangi efek hipoksia.

\section{Batang}

Batang tampaknya menjadi organ yang terpengaruh paling sedikit terhadap stress lingkungan dibandingkan dengan daun dan akar. berbagai penelitian lebih fokus pada adaptasi anatomis daun dan akar arena kedua organ tersebut yang paling terlihat perubahan parameter anatomisnya. Sekalipun demikian, pada beberapa stress lingkungan yang berkepanjangan, batang juga menampakkan adaptasi anatomisnya untuk menyesuaikan diri dengan lingkungannya.

Di lingkungan kering disertai kadar garam tinggi, batang biasanya memiliki kutikula yang tebal. Pada batang Z. album memiliki sel-sel fiber yang kuat di sekitar floem untuk mengokohkan batang (Abd Elhalim et al., 2016), dan pada batang Cyperus alopecuroides juga ditemukan sklerifikasi di sekitar berkas pengangkut (Nawaz et al., 2014). Pada batang Nitriaria sp., ditemukan sel mucilage yang berfungsi untuk meningkatkan tekanan osmotik sehingga kapasitas retensi air dan absoprsi air akan meningkat. Sementara itu, batang Sporobolus ioclados menunjukkan penebalan epidermis (Naz et al., 2016) dimana repon yang mirip teramati pada batang Echinocactus grusonii (Nuzhyna et al., 2018) yang mengalami stress suhu tinggi. Sedikit berbeda dengan batang Astrogalus gambiformis yang juga tercekam kekeringan, epidermis batangnya tidak mengalami penebalan yang menunjukkan bahwa spesies ini cukup toleran pada kekeringan (Fayçal Boughalleb et al., 2014). Walaupun demikian, parameter lain seperti diameter empulur, diameter trakea xylem dan ketebalan xylem menurun seiring dengan kekeringan. Stress abiotik seperti paparan logam berat Ni teramati akan menurunkan diameter batang dan jumlah berkas pengangkut dan ukuran sel-sel yang ada (Batool et al., 2015). Cekaman lain seperti genangan mendorong $\mathrm{R}$. palustris melakukan upaya menghindar dengan cara memanjangkan batangnya karena peningkatan hormone Giberelin (Ahammed \& Yu, 2016).

\section{SIMPULAN DAN SARAN}

Berbagai adaptasi anatomis yang ada pada tumbuhan menunjukkan bahwa perubahan struktur internal juga akan mempengaruhi morfologi organ. Permasalahan ini semakin menantang di masa perubahan iklim karena pada tumbuhanlah manusia bergantung misalnya dalam penyediaan oksigen, membantu peresapan air, juga khususnya pada tumbuhan pangan yang sangat penting. Oleh karena itu perlu dilakukan upaya untuk membantu tumbuhan dalam mengembangkan mekanisme adaptasi anatomisnya. Stress lingkungan dapat menimbulkan penyakit pada tumbuhan. Pemakaian PGPR dapat membantu tumbuhan menghadapi fitopatogen dengan cara memodifikasi dinding sel dengan penebalan lignin dan callosa apposition (Jha, 2018). (Vidya Vardhini, 2017) menayarankan bahwa penggunaan hormone Brassinosteroid dapat menghindarkan Brassica juncea, Brassica napus dan Brassica carinata dari cekaman suhu tinggi dengan mendorong pertumbuhannya. Selain itu, (Ghafoor et al., 2019) menyatakan bahwa pemberian proline eksogen pada Avena sativa yang tercekam kekeringan dapat meningkatkan luas metaxylem akar, tebal mesofil, diameter 
akar, tebal korteks akar, tebal epidermis akar, tebal endodermis endodermis, diameter stele, luas metaxylem batang, diameter batang, luas berkas pengangkut batang, luas epidermis batang, luas floem batang dan tebal sklerenkim batang.

Pemuliaan tumbuhan yang tahan cekaman juga sangat penting dilakukan untuk menghasilkan benih yang adaptif di era perubahan iklim ini. Pemilihan varietas tahan cekaman garam seperti kedelai Glycine max varietas Wilis, Malabar, dan Sindoro untuk ditanam di lahan dengan kandungan garam tinggi (Yuniati, 2010). Pada ketiga varietas tersebut masih menunjukkan pertumbuhan yang baik saat pemberian $\mathrm{NaCl}$ dengan konsentrasi 80 $\mathrm{mM}$. para peneliti perlu terus melakukan pemuliaan pada spesies lain sehingga dapat membantu kelestarian jenis maupun ketahanan pangan nasional.

\section{DAFTAR PUSTAKA}

Abd Elhalim, M. E., Abo-Alatta, O. K., Habib, S. A., \& Abd Elbar, O. H. (2016). The anatomical features of the desert halophytes Zygophyllum album L.F. and Nitraria retusa (Forssk.) Asch. Annals of Agricultural Sciences, 61(1), 97-104. https://doi.org/10.1016/j.aoas.2015.12 .001

Adame-González, A. B., Muñíz-DL, M. E., \& Valencia-A., S. (2019). Comparative leaf morphology and anatomy of six Selaginella species (Selaginellaceae, subgen. Rupestrae) with notes on xerophytic adaptations. Flora: Morphology, Distribution, Functional Ecology of Plants, 260. https://doi.org/10.1016/j.flora.2019.15 1482

Ahammed, G. J., \& Yu, J. Q. (2016). Plant hormones under challenging environmental factors. Plant Hormones under Challenging Environmental Factors, 1-269. https://doi.org/10.1007/978-94-0177758-2

Akmalia, Hafidha Asni; E. Suharyanto.
(2017). Respon fisiologis dan produktivitas jagung (Zea mays L) "Sweet Boy-02" pada perbedaan intensitas cahaya dan penyiraman. Jurnal Teknosains, 6131(2 L), 59-138. https://doi.org/10.22146/teknosains.2

Akmalia, H. A., \& Suharyanto, E. (2017). Respon anatomis jagung (Zea Mays L.) 'Sweet Boy-02' pada perbedaan intensitas cahaya dan penyiraman. Jurnal EduMatSains, 1(2), 95-106. https://doi.org/10.21831/jsd.v6i1.1340 3

Alkhatib, R., Alkhatib, B., Al-Eitan, L., Abdo, N., Tadros, M., \& Bsoul, E. (2018). Physio-anatomical responses of tobacco under caffeine stress. Photosynthetica, 56(4), 1140-1146. https://doi.org/10.1007/s11099-0180798-4

Batool, R., Hameed, M., Ashraf, M., \& Sajid, M. (2015). Phytoremediation for Green Energy. Phytoremediation for Green Energy, 79-96. https://doi.org/10.1007/978-94-0077887-0

Boughalleb, Façal, Abdellaoui, R., Hadded, Z., \& Neffati, M. (2015). Anatomical adaptations of the desert species Stipa lagascae against drought stress. Biologia (Poland), 70(8), 1042-1052. https://doi.org/10.1515/biolog-20150125

Boughalleb, Fayçal, Abdellaoui, R., BenBrahim, N., \& Neffati, M. (2014). Anatomical adaptations of Astragalus gombiformis Pomel. under drought stress. Central European Journal of Biology, 9(12), 1215-1225. https://doi.org/10.2478/s11535-0140353-7

Boughalleb, Fayçal, Abdellaoui, R., Nbiba, N., Mahmoudi, M., \& Neffati, M. (2017). Effect of $\mathrm{NaCl}$ stress on physiological, antioxidant enzymes and anatomical responses of Astragalus gombiformis. Biologia (Poland), 72(12), 1454-1466. https://doi.org/10.1515/biolog-20170169 
D. Kartikaningtyas, O. Quirena, Suharyanto, S. S. (2013). Respon anatomis Acacia mangium Willd. terhadap kondisi cekaman garam: Observasi awal untuk program pemuliaan tanaman. Wana Benih, 14 (2), 95-102.

Ekawati, R., \& Aziz, S. A. (2016). Respon petumbuhan dan fisiologi plectranthus amboinicus (Lour.) spreng pada sekaman naungan. Agrovigor, 9(2), 82-89.

Ely F., Torres, F., 2003. Adaptaciones anatomico-estructurales foliares deChaetolepis lindenianan (Naud.) Triana a lo largo de una gradiente altitudinalen el Paramo del Parque Nacional Sierra Nevada de Merida (Venezuela).Plantula 3, 101-115.

Ge, W., Zhang, Y., Sun, Z., Li, J., Liu, G., Ma, Y., \& Gao, J. (2017). Physiological and anatomical responses of Phyllostachys vivax and Arundinaria fortunei (Gramineae) under salt stress. Revista Brasileira de Botanica, 40(1), 79-91. https://doi.org/10.1007/s40415-0160335-2

Ghafoor, R., Akram, N. A., Rashid, M., Ashraf, M., Iqbal, M., \& Lixin, Z. (2019). Exogenously applied proline induced changes in key anatomical features and physio-biochemical attributes in water stressed oat (Avena sativa L.) plants. Physiology and Molecular Biology of Plants, 25(5), 1121-1135.

https://doi.org/10.1007/s12298-01900683-3

Gratani, L., Catoni, R., \& Varone, L. (2013). Morphological, anatomical and physiological leaf traits of Q. ilex, P. latifolia, P. lentiscus, and M. communis and their response to Mediterranean climate stress factors. Botanical Studies, 54(1), 1-12. https://doi.org/10.1186/1999-311054-35

Grzesiak, S., Hura, T., Grzesiak, M. T., \& Pieńkowski, S. (1999). The impact of limited soil moisture and waterlogging stress conditions on morphological and anatomical root traits in maize (Zea mays L.) hybrids of different drought tolerance. Acta Physiologiae Plantarum, 21(3), 305-315. https://doi.org/10.1007/s11738-9990046-4

Gupta, G. P., Kumar, B., Singh, S., \& Kulshrestha, U. C. (2016). Deposition and impact of urban atmospheric dust on two medicinal plants during different seasons in NCR delhi. Aerosol and Air Quality Research, 16(11), 2920-2932. https://doi.org/10.4209/aaqr.2015.04. 0272

Jha, Y. (2018). Role of Rhizospheric Microbes in Soil. Role of Rhizospheric Microbes in Soil, 125-141. https://doi.org/10.1007/978-981-108402-7

Jiménez-Noriega, P. M. S., Terrazas, T., López-Mata, L., Sánchez-González, A., \& Vibrans, H. (2017). Anatomical variation of five plant species along an elevation gradient in Mexico City basin within the Trans-Mexican Volcanic Belt, Mexico. Journal of Mountain Science, 14(11), 21822199. https://doi.org/10.1007/s11629017-4442-8

Khan, M. N. I., \& Kabir, M. E. (2017). Ecology of Kandelia obovata (S., L.) Yong: A Fast-Growing Mangrove in Okinawa, Japan. April, 287-301. https://doi.org/10.1007/978-4-43156481-2_18

Khan, M. N. I., Khatun, S., Azad, M. S., \& Mollick, A. S. (2020). Leaf morphological and anatomical plasticity in Sundri (Heritiera fomes Buch.-Ham.) along different canopy light and salinity zones in the Sundarbans mangrove forest, Bangladesh. Global Ecology and Conservation, 23, e01127. https://doi.org/10.1016/j.gecco.2020.e 01127

Khan, W.-D., Tanveer, M., Shaukat, R., Ali, 
M., \& Pirdad, F. (2020). Salt and Drought Stress Tolerance in Plants. http://link.springer.com/10.1007/9783-030-40277-8

Kriebel, R. (2015). New insights into anatomical and morphological adaptations to high elevations in the Melastomataceae: Evidence from Chaetolepis cufodontisii and Monochaetum amabile. Flora: Morphology, Distribution, Functional Ecology of Plants, 213, 12-19. https://doi.org/10.1016/j.flora.2015.03 .002

Kulshrestha, U., \& Saxena, P. (2016). Plant responses to air pollution. Plant Responses to Air Pollution, 1-195. https://doi.org/10.1007/978-981-101201-3

Kuster, V. C., da Silva, L. C., Meira, R. M. S. A., \& Azevedo, A. A. (2018). Structural adaptation and anatomical convergence in stems and roots of five plant species from a "Restinga" sand coastal plain. Flora: Morphology, Distribution, Functional Ecology of Plants, 243, 77-87. https://doi.org/10.1016/j.flora.2018.03 .017

Lamalakshmi Devi, E., Kumar, S., Basanta Singh, T., Sharma, S. K., Beemrote, A., Devi, C. P., Chongtham, S. K., Singh, C. H., Yumlembam, R. A., Haribhushan, A., Prakash, N., \& Wani, S. H. (2017). Adaptation strategies and defence mechanisms of plants during environmental stress. In Medicinal Plants and Environmental Challenges. https://doi.org/10.1007/978-3-31968717-9 20

Li, J., Yu, J., Du, D., Liu, J., Lu, H., \& Yan, C. (2019). Analysis of anatomical changes and cadmium distribution in Aegiceras corniculatum (L.) Blanco roots under cadmium stress. Marine Pollution Bulletin, 149(April), 110536.

https://doi.org/10.1016/j.marpolbul.20 19.110536

Mahajan, M., Kuiry, R., \& Pal, P. K. (2020).
Understanding the consequence of environmental stress for accumulation of secondary metabolites in medicinal and aromatic plants. Journal of Applied Research on Medicinal and Aromatic Plants, 18(April), 100255. https://doi.org/10.1016/j.jarmap.2020. 100255

Minkina, T., Rajput, V., Fedorenko, G., Fedorenko, A., Mandzhieva, S., Sushkova, S., Morin, T., \& Yao, J. (2020). Anatomical and ultrastructural responses of Hordeum sativum to the soil spiked by copper. Environmental Geochemistry and Health, 42(1), 4558. https://doi.org/10.1007/s10653019-00269-8

Nawaz, T., Hameed, M., Ashraf, M., Ahmad, M. S. A., Batool, R., \& Fatima, S. (2014). Anatomical and physiological adaptations in aquatic ecotypes of Cyperus alopecuroides Rottb. under saline and waterlogged conditions. Aquatic Botany, 116, 6068.

https://doi.org/10.1016/j.aquabot.2014 .01 .001

Naz, N., Fatima, S., Hameed, M., Naseer, M., Batool, R., Ashraf, M., Ahmad, F., Ahmad, M. S. A., Zahoor, A., \& Ahmad, K. S. (2016). Adaptations for salinity tolerance in Sporobolus ioclados (Nees ex Trin.) Nees from saline desert. Flora: Morphology, Distribution, Functional Ecology of Plants, 223, 46-55. https://doi.org/10.1016/j.flora.2016.04 .013

Nio Song, A., \& Banyo, Y. (2011). Konsentrasi Klorofil Daun Sebagai Indikator Kekurangan Air Pada Tanaman. Jurnal Ilmiah Sains, 15(1), 166. https://doi.org/10.35799/jis.11.2.2011. 202

Nuzhyna, N., Baglay, K., Golubenko, A., \& Lushchak, O. (2018). Anatomically distinct representatives of Cactaceae Juss. family have different response to acute heat shock stress. Flora: 
Morphology, Distribution, Functional Ecology of Plants, 242(March), 137145.

https://doi.org/10.1016/j.flora.2018.03 .014

Osakabe, Y., \& Osakabe, K. (2012). Abiotic stress responses in plants. Abiotic Stress: New Research, 171-180. https://doi.org/10.1007/978-1-46140634-1

Punwong, P., Juprasong, Y., \& Traiperm, P. (2017). Effects of an oil spill on the leaf anatomical characteristics of a beach plant (Terminalia catappa L.). Environmental Science and Pollution Research, 24(27), 21821-21828. https://doi.org/10.1007/s11356-0179814-7

Reyes-Díaz, M., Meriño-Gergichevich, C., Inostroza-Blancheteau, C., Latsague, M., Acevedo, P., \& Alberdi, M. (2016). Anatomical, physiological, and biochemical traits involved in the UV-B radiation response in highbush blueberry. Biologia Plantarum, 60(2), 355-366.

https://doi.org/10.1007/s10535-0150580-4

Rosawanti, P., Ghulamahdi, M., Khumaida, N., Agroteknologi, J., Pertanian, F., Muhammadiyah, U., Rta, J., Km, M., \& Tengah, K. (2015). Respon Anatomi dan Fisiologi Akar Kedelai terhadap Cekaman Kekeringan Anatomical and Physiological Responses of Soybean Root to Drought Stress. J. Agron. Indonesia 43 (3) : 186 - 192, 43(3), 186-192.

Shi, G. R., \& Cai, Q. S. (2009). Photosynthetic and anatomic responses of peanut leaves to zinc stress. Biologia Plantarum, 53(2), 391-394.

https://doi.org/10.1007/s10535-0090074-3

Svobodníková, L., Kummerová, M., Zezulka, Š., Babula, P., \& Sendecká, K. (2020). Root response in Pisum sativum under naproxen stress: Morpho-anatomical, cytological, and biochemical traits. Chemosphere, 258 . https://doi.org/10.1016/j.chemosphere .2020 .127411

Vidya Vardhini, B. (2017). Modifications of morphological and anatomical characteristics of plants by application of brassinosteroids under various abiotic stress conditions - A review. Plant Gene, 11, 70-89. https://doi.org/10.1016/j.plgene.2017. 06.005

Yadav, V., Arif, N., Kováč, J., Singh, V. P., Tripathi, D. K., Chauhan, D. K., \& Vaculík, M. (2021). Structural modifications of plant organs and tissues by metals and metalloids in the environment: A review. Plant Physiology and Biochemistry, 159, 100-112.

https://doi.org/10.1016/j.plaphy.2020. 11.047

Yin, D., Zhang, Z., \& Luo, H. (2012). Anatomical responses to waterlogging in Chrysanthemum zawadskii. Scientia Horticulturae, 146, 86-91. https://doi.org/10.1016/j.scienta.2012. 08.019

Yuniati, R. (2010). PENAPISAN GALUR KEDELAI Glycine max (L.) Merrill TOLERAN TERHADAP $\mathrm{NaCl}$ UNTUK PENANAMAN DI LAHAN SALIN. MAKARA of Science Series, $8(1)$, 21-24. https://doi.org/10.7454/mss.v8i1.387

Zhao, C., Zhang, H., Song, C., Zhu, J.-K., \& Shabala, S. (2020). Mechanisms of Plant Responses and Adaptation to Soil Salinity. The Innovation, 1(1), 100017. https://doi.org/10.1016/j.xinn.2020.10 0017

Zhou, Y., Huang, L., Wei, X., Zhou, H., \& Chen, X. (2017). Physiological, morphological, and anatomical changes in Rhododendron agastum in response to shading. Plant Growth Regulation, $\quad 81(1), \quad 23-30$. https://doi.org/10.1007/s10725-0160181-z

Zhou, Y., Wang, Y., Li, M., Gao, Z., Hu, 
Q., \& Gao, S. (2014). Anatomical and biochemical characteristics of Achnatherum splendens (Trin.) Nevski seedlings stressed on $\mathrm{Pb} 2+$. Applied Biochemistry and
Biotechnology, 172(6), 3176-3193. https://doi.org/10.1007/s12010-0140748-y 